\title{
ARTICLE
}

\section{Influence of different grazing intensity on above-ground biomass in Mongolian rangeland}

\author{
Lkhagvajav Otgontuya $^{I}$, Asrun Elmarsdottir ${ }^{2 *}$, Namdag Lkhagvajav ${ }^{I}$ and Chimed Munkhbat \\ ${ }^{I}$ Branch of Research Institute of Animal Husbandry in Arkhangai, Mongolia \\ Mongolian University of Life Science, Ulaanbaatar, Mongolia \\ ${ }^{2}$ Landsvirkjun National Power Company, Iceland
}

\begin{abstract}
In the last two decades, the quality of Mongolian rangeland has degraded primarily owing to overgrazing and climate change. This has government challenged to improve land usage and gather information about the tolerance of the rangeland. The aim of this research was to examine the effect of cutting frequency (four, three, two and one), cutting height ( 0 and $3 \mathrm{~cm}$ ) and duration of cutting on aboveground biomass at different degradation levels of Fescue-forbs rangeland. Three sites were selected with different degradation levels; slightly, moderately and heavily degraded.

The cutting experiment was randomized with complete block design with five replications. Samplings were carried out in 2006, 2007 and 2008. In 2009, all the plots of rangelands were cut at the same time in August and at $0 \mathrm{~cm}$ height and the results were analyzed. The results showed that total biomass was influenced by cutting frequency, cutting height and the duration of cutting. Biomass decreased considerably with increasing cutting frequency in most cases when cutting height was $0 \mathrm{~cm}$ but small changes were noticed when cutting height was $3 \mathrm{~cm}$. The biomass decreased by 30-54\% when cut four times a year at $0 \mathrm{~cm}$ in slightly-and moderately-degraded sites. Year of duration influenced biomass significantly at slightly-and heavily degraded sites.
\end{abstract}

Keywords: grazing intensity; above-ground biomass; cutting frequency; cutting height; year duration;

\section{INTRODUCTION}

Many parts of the world are degraded due to overgrazing and severe climatic conditions [8; 13]. Increasingly less land cover has become available for grazing, owing primarily to growing irrational actions of humans, which makes it more important to manage the land properly [4]. This situation has challenged range managers throughout the world to repair rangelands during the last few decades. To accomplish this, herders and range managers must have a good understanding of the tolerance of rangelands and plants as well as the ecosystem structure.

About $80 \%$ of the Mongolian total land area can be considered rangeland [6]. Mongolia's nomadic animal husbandry is reliant on 
natural rangeland and livestock production is an important part of the economy. Today, Mongolia is one of the most heavily grazed countries in the world [1]. From 1990 to 2017, the total number of herding households in Mongolia doubled and the livestock population increased by 2.5 times to count more than 66.2 million heads of animals [14; 15]. Mongolia has no restriction on the maximum number of livestock a herder family can own, which makes the rangeland potentially susceptible to overgrazing and degradation [16].

In Mongolia, the ownership of land has changed in the past few decades. For centuries herders moved from one grazing area to another with their herd, and the impact of grazing was not so intense at each place. Following 1921, when the communists ruled the country individuals could not own livestock, instead they herded state-owned animals on stateowned rangelands for a salary. Although nomadic movements were restricted during the socialist period, collective farms were allowed seasonal movements and rangeland use was regulated [10]. Grazing methods changed after 1990 when herding collective farms were dismissed and the entirety of the state-owned livestock was privatized. However, rangeland remained under state ownership but herders could utilize them. Following privatization, the number of herding households increased, while seasonal movements of herders decreased [7].

The effect of grazing is traditionally viewed as negative on primary production through a series of direct and indirect effects on plant growth [1]. Although many plant species are well adapted to defoliation, domestic livestock can substantially impact their growth and persistence in numerous ways [1]. The aboveground parts of plants are destroyed, but in addition, plants suffer from trampling [8]. In cases of heavy grazing it is well known that plant composition changes and can result in vegetation and land degradation [5]. The influence of grazing on grass cover has a more complicated character when combined with natural shortages of water.

Because of heavy grazing and climate changes in Mongolia it is important not only to gather information about the grazing tolerance of the land but also about methods that can be used to restore degraded land. Such data will serve as basic information essential for the assessment of the carrying capacity of the pastures and for management of decisions for a sustainable use of the natural rangeland. In this research, we seek to examine the effect of different grazing management intensities (cutting frequencies and cutting heights) on the above-ground biomass of different degradation level following three years (2006-2008) of utilization. To approach these objectives, the research was applied in Fescue-forbs rangelands in the Khangai mountain region of Mongolia.

\section{MATERIALS AND METHODS}

\section{Study area}

The study area covers the forest steppe belt in the Khangai mountain region, which is located at Ikhtamir soum, Arkhangai aimag (province) of Mongolia $\left(47^{\circ} 47^{\prime}-47^{\circ} 50^{\prime} \mathrm{N}\right.$; $\left.100^{\circ} 56^{\prime}-100^{\circ} 54^{\prime} \mathrm{E}\right)$. The altitude of the study area is between 1793 and $1844 \mathrm{~m}$ above sea level.

The climate at the study area is extreme continental [2]. Average wind speed is 2.3 $\mathrm{m} / \mathrm{sec}$ and maximum speed is $20 \mathrm{~m} / \mathrm{sec}$. The long-term average temperature is $0.8^{\circ} \mathrm{C}$ and the monthly minimum temperature is $-14.8^{\circ} \mathrm{C}$ in January and the maximum temperature is $15.4^{\circ} \mathrm{C}$ in July. Annual temperature fluctuated quite significantly in the years from 2004 to 2009. The highest temperature was in 2007 and the lowest was in 2005 (Fig. 1a). Within each year annual temperature was usually higher than the long-term average except for the year 2005 . 
The average long-term (1970-2010) precipitation is $329.3 \mathrm{~mm}$ (Fig. 1b) (Institute of Meteorology and Hydrology, 2012). Annual precipitation year-on-year was always lower than LTA except for 2007, however, the summer precipitation (about $190 \mathrm{~mm}$ ) was

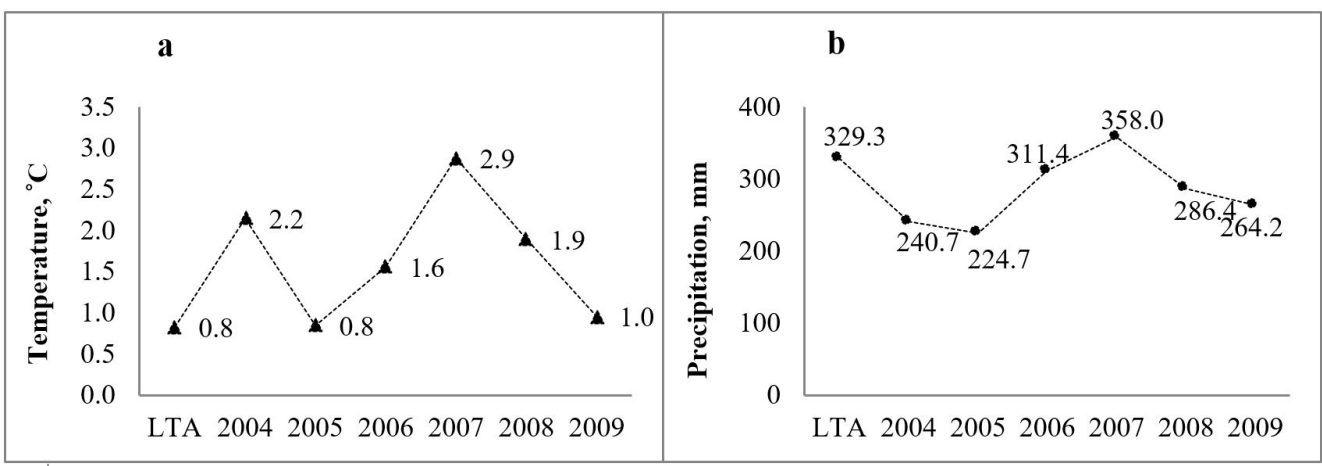

Figure. 1. a) Annual temperature $\left({ }^{\circ} \mathrm{C}\right)$, and b) precipitation ( $\mathrm{mm}$ ) at Tsetserleg station in Arkhangai aimag and long-term average of climate data from 1970-2010 (LTA) (Institute of Meteorology and Hydrology,

2012). Tsetserleg station is $80 \mathrm{~km}$ from the study area

The vegetation at the study area is Fescue-forbs community which is a common vegetation type in the mountain forest steppe [11]. The grass Festuca lenensis was a dominant species in the community and is considered as one of the main indicator species for healthy rangeland. Coverage of Festuca lenensis was about $21.5 \%$ of total cover and $25-30 \%$ of total biomass in earlier research $[11 ; 18]$. Studies in 2002 showed that there was more than $90 \%$ of Festuca lenensis cover, but the abundance has decreased since $1986[11 ; 12]$.

\section{Experimental design and methods}

There are three experimental sites within the study areas (Table 1). Within each site, a 1 ha area was fenced off in 2004 with as much mainly after 20th of August when it was too late for plant growth. On an average, more than $80 \%$ of precipitation is distributed during the growing season of plants, which is between May and August.

Table 1. The experimental sites wer at three different degradation levels and different vegetation type of Fescue-forbs community in 2004

\begin{tabular}{|l|l|l|}
\hline Study area & Degradation level & Vegetation type \\
\hline \multirow{3}{*}{ Fescue-forbs } & Slightly degraded & Grass-forbs \\
\cline { 2 - 3 } & Moderately degraded & Artemisia-forbs \\
\cline { 2 - 3 } & Heavily degraded & Sedge-forbs \\
\hline
\end{tabular}


The slope is $2.5 \%$ in slightly and moderately degraded sites and $1 \%$ in heavily degraded site. Aspects are $254^{\circ}$ and $245^{\circ}$ in slightly and moderately degraded sites and $315^{\circ}$ in heavily degraded site.

Cover of degradation indicator species was highest in sedge-forbs community and it was lowest in grass-forbs community (Table-2).

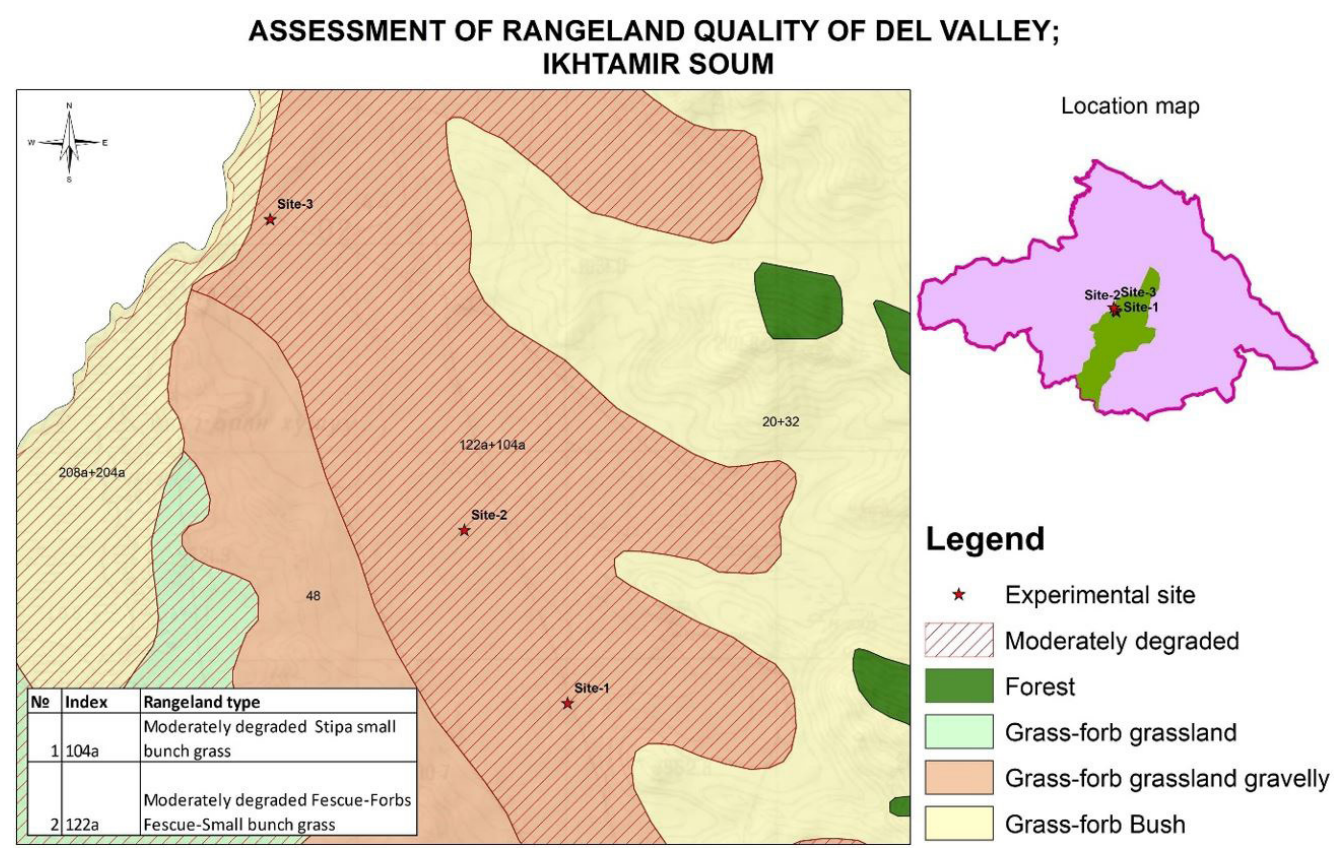

Picture 1. Location of experimental sites. 1-slightly degraded, 2-moderately degraded, 3-heavily degraded site

Table-2. Assessment of degradation levels for Fescue-forbs rangeland

\begin{tabular}{|l|l|c|c|c|}
\hline № & Community & $\begin{array}{c}\text { Cover of degradation } \\
\text { indicator species, \% }\end{array}$ & $\begin{array}{c}\text { Number of degradation } \\
\text { indicator species }\end{array}$ & $\begin{array}{c}\text { Degradation } \\
\text { level }\end{array}$ \\
\hline 1 & Grass-forbs & 12.5 & 4 & Slight \\
\hline 2 & Artemisia-forbs & 34.3 & 5 & Moderate \\
\hline 3 & Sedge-forbs & 69.3 & 4 & Heavy \\
\hline
\end{tabular}

\section{Cutting experiment}

The cutting experiment included three factors (Table 2); 1) Cutting height: aboveground biomass was cut at two different heights above ground level. At $0 \mathrm{~cm}$ the vegetation was cut at surface level and the other height was $3 \mathrm{~cm}$ above surface. 2) Cutting frequency: above-ground biomass was cut at four different frequencies within the same growing season. The cutting was applied monthly; four times (May, June, July and August), three times (June, July and August) and two times (July and August) and one time (August) respectively. 3) Duration: the duration of the cutting treatments was different; for three years (2006-2008), two years (2007-2008) and one year (2008). 
Table 2. Treatments repeated within fenced area of each experimental site

\begin{tabular}{|c|c|c|c|c|c|c|c|c|}
\hline Year & \multicolumn{4}{|c|}{ Cutting height-cutting frequency } & \multicolumn{4}{c|}{ Cutting height-cutting frequency } \\
\hline 2006 & $0-4$ & $0-3$ & $0-2$ & $0-1$ & $3-4$ & $3-3$ & $3-2$ & $3-1$ \\
\hline 2007 & $0-4$ & $0-3$ & $0-2$ & $0-1$ & $3-4$ & $3-3$ & $3-2$ & $3-1$ \\
\hline 2008 & $0-4$ & $0-3$ & $0-2$ & $0-1$ & $3-4$ & $3-3$ & $3-2$ & $3-1$ \\
\hline 2009 & $0-1$ & $0-1$ & $0-1$ & $0-1$ & $0-1$ & $0-1$ & $0-1$ & $0-1$ \\
\hline
\end{tabular}

The treatments included different cutting height $(0$ and $3 \mathrm{~cm}$ ), different cutting frequencies (4=May, June, July and August, $3=$ June, July and August, $2=$ July and August and $1=$ August). Numbers indicate number of plots for each cutting height and cutting frequency. Treatment started in year 2006 and duration of treatments was different (One year $=2008$, two years $=2007-2008$ and three $=2006-2008$. Each treatment was replicated five times. In 2009 all plots were cut during the peak yield season (in August) by $0 \mathrm{~cm}$.

In total of 360 plots were randomly chosen for the cutting experiment within the three fenced areas, which had different degradation levels. Within each fence a total of 120 (1x 1 $\mathrm{m})$ plots were randomly chosen and they were separated from each other by $0.5 \mathrm{~m}$ buffer strips. During the first year (2006) of the study five plots were randomly chosen for each cutting frequency and cutting height, and in total 40 plots were selected (Table 2). The duration of cutting treatments for those plots were three years, they were cut the same way in 2006, 2007 and 2008. In 2007 and 2008 another set of plots were selected following the same setup. Plots established in 2007 were cut for two years and those established in 2008 for one year. In 2009 all 360 plots were cut once in August at $0 \mathrm{~cm}$. Each treatment was randomly assigned to five blocks or replicates and the design of the experiment was fully factorial.

The measurements were carried out during the growing season, from May to August (Table 2). Biomass was obtained from the plots on the 20th of every month and cutting

\section{RESULTS AND DISCUSSION}

During the study period, climatic condition was different each year. But we conducted control study in 2009 and climatic condition was same for all treatments. Overall, ANOVA analyses showed that cutting height and cutting frequency had significant effect on biomass in both slightly and moderately degraded sites, was done by hand. All plant material was air dried at room temperature for 20-25 days and then weighed. In the beginning of April each year, before the growing season, dead biomass from the previous year was removed.

\section{Analysis}

We ran two-way ANOVA for block design on data from year 2009 [17] in order to estimate the effect on total biomass of different cutting heights and cutting frequencies during the years from 2006 to 2008. Each treatment was replicated five times. Each different degradation level was analyzed separately. With two-way ANOVA you get differences between cutting frequencies and different cutting heights, which revealsif there is any interaction between cutting frequency and height. Twoway ANOVA was also used to estimate the effect on total biomass of duration and cutting frequencies and indicated interaction between duration and cutting frequency by two different cutting heights separately. Statistical analysis was performed using SAS (Enterprise Guide 4.2) for Windows.

regardless of the duration of cutting (Table 3 ). In heavily degraded site cutting frequency and cutting height was not significant, except cutting height of duration of two and three years of cutting (Table 3). Furthermore, duration of treatments had different effects, which depended on the cutting height (Table 4). 


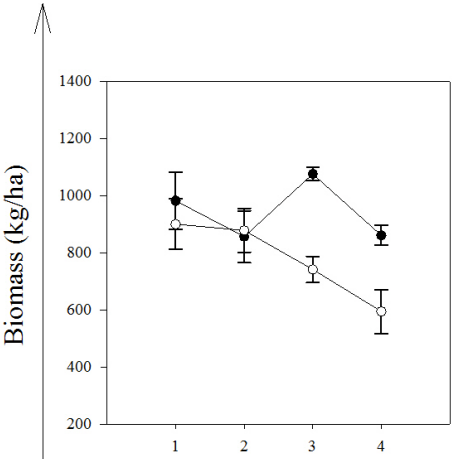

SD

One year
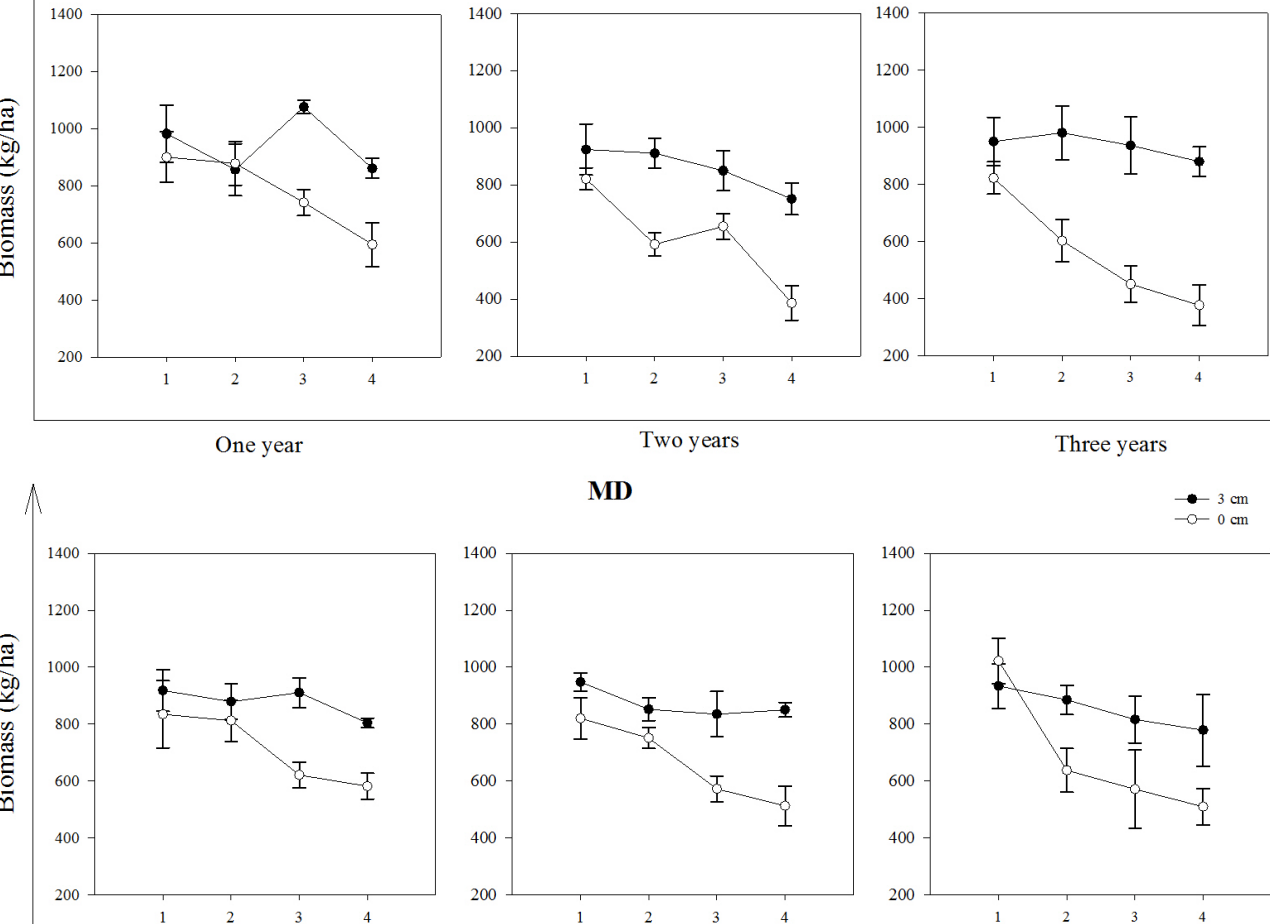

Two years

Three years

MD
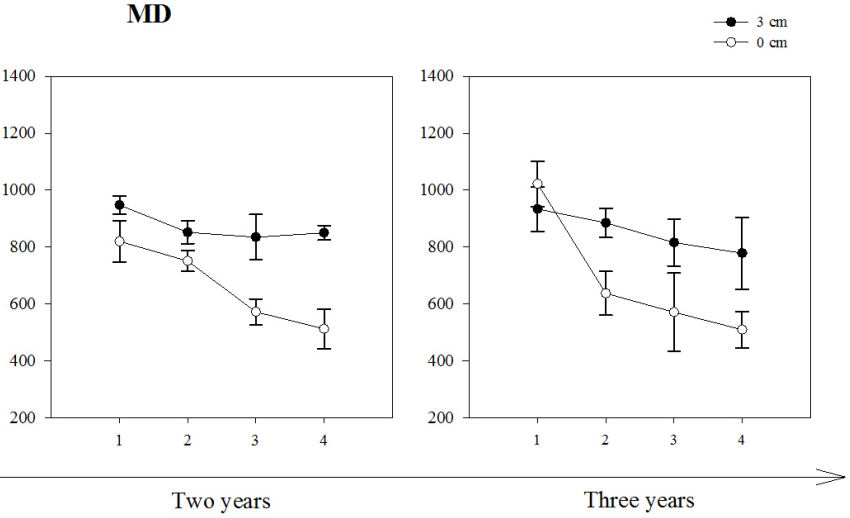

One year

HD

$-3 \mathrm{~cm}$
$-0-0 \mathrm{~cm}$

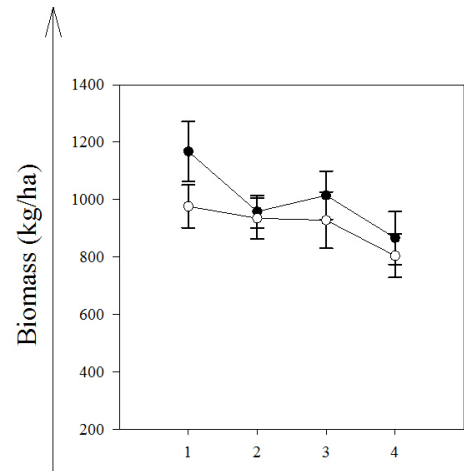

One year

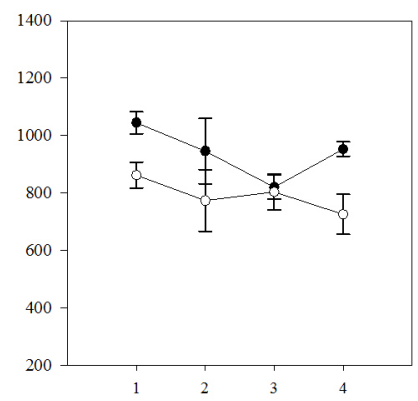

Two years

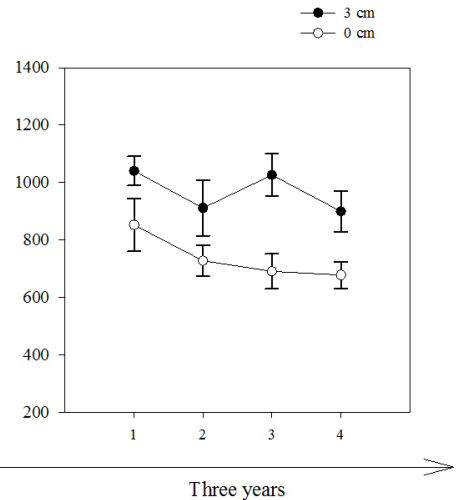

Figure 2. Weight (kg/ha) of above-ground biomass in 2009 within slightly degraded (SD), moderately degraded (MD) and heavily degraded (HD) sites

The treatments included different cutting heights $(0$ and $3 \mathrm{~cm})$, different cutting frequencies

(1-August, 2-July and August, 3-June, July and August, and 4-May, June, July and August,) and different duration of treatments (One year-2008, two years-2007-2008 and three years-2006-2008) 
Within the slightly degraded site, the cutting frequency had no significant effect $(\mathrm{P}<0.1176)$ on biomass when cutting height was $3 \mathrm{~cm}$ (Table 4; Fig. 2). The biomass decreased considerably with increased cutting frequency when cutting height was $0 \mathrm{~cm}$. During the first year, the biomass decreased by $34 \%$ when cut four times compared with one cutting. Then in the second and third years the biomass decreased by $53-54 \%$ when the vegetation was cut four times compared with one cutting at $0 \mathrm{~cm}$. Interaction between cutting frequency and cutting height was significant $(\mathrm{P}<0.0375)$ at year one, but not significant $(\mathrm{P}>0.05)$ for two and three years (Table 3). The duration of treatments significantly affected biomass when cutting height was $0 \mathrm{~cm}$ (Table 4). For example, biomass was $594.2 \mathrm{~kg} / \mathrm{ha}$ when cut four times for one year, but it was $377 \mathrm{~kg} / \mathrm{ha}$ when cut four times for three years (Fig. 2). Interaction between year duration and cutting frequency $\left(\mathrm{YD}^{*} \mathrm{CF}\right)$ was not significant $(\mathrm{P}>0.05)$ regardless of cutting (Table 4$)$.

Table 3. Results of two-way ANOVA for above-ground biomass in plots harvested in 2009 within slightly degraded (SD), moderately degraded (MD) and heavily degraded (HD) sites

\begin{tabular}{|c|c|c|c|c|c|c|c|c|}
\hline \multirow{3}{*}{ Treatment } & \multirow{3}{*}{ Source } & \multirow{3}{*}{$D F$} & \multicolumn{6}{|c|}{ Duration } \\
\hline & & & \multicolumn{2}{|c|}{ One year } & \multicolumn{2}{|c|}{ Two years } & \multicolumn{2}{|c|}{ Three years } \\
\hline & & & $F$ & $P r>F$ & $F$ & $P r>F$ & $F$ & $P r>F$ \\
\hline \multirow{4}{*}{$\begin{array}{l}\text { Slightly } \\
\text { degraded }\end{array}$} & Replicate & 4 & 2.99 & 0.0359 & 1.14 & 0.3575 & 0.25 & 0.9102 \\
\hline & $\mathrm{CF}$ & 3 & 4.23 & 0.0138 & 9.28 & 0.0002 & 3.97 & 0.0178 \\
\hline & $\mathrm{CH}$ & 1 & 13.06 & 0.0012 & 35.57 & $<.0001$ & 43.46 & $<.0001$ \\
\hline & $\mathrm{CF}^{*} \mathrm{CH}$ & 3 & 3.23 & 0.0375 & 2.08 & 0.1257 & 2.33 & 0.0961 \\
\hline \multirow{4}{*}{$\begin{array}{l}\text { Moderately } \\
\text { degraded }\end{array}$} & Replicate & 4 & 1.72 & 0.1743 & 1.24 & 0.3149 & 1.38 & 0.2661 \\
\hline & $\mathrm{CF}$ & 3 & 3.33 & 0.0337 & 6.24 & 0.0022 & 5.41 & 0.0046 \\
\hline & $\mathrm{CH}$ & 1 & 13.39 & 0.001 & 30.7 & $<.0001$ & 7.06 & 0.0129 \\
\hline & $\mathrm{CF}^{*} \mathrm{CH}$ & 3 & 1.42 & 0.2574 & 2.24 & 0.1053 & 1.83 & 0.1647 \\
\hline \multirow{4}{*}{$\begin{array}{l}\text { Heavily } \\
\text { degraded }\end{array}$} & Replicate & 4 & 0.32 & 0.8615 & 3.92 & 0.0119 & 4.13 & 0.0093 \\
\hline & $\mathrm{CF}$ & 3 & 2.5 & 0.0798 & 2.09 & 0.1248 & 2.62 & 0.0706 \\
\hline & $\mathrm{CH}$ & 1 & 2.19 & 0.1502 & 12.38 & 0.0015 & 30.23 & $<.0001$ \\
\hline & $\mathrm{CF}^{*} \mathrm{CH}$ & 3 & 0.34 & 0.7953 & 1.16 & 0.3411 & 0.71 & 0.5555 \\
\hline
\end{tabular}

The abbreviations are; $C F$-different cutting frequencies, $\mathrm{CH}$-cutting height, Duration-duration of treatments. Bold figures indicate significant differences $(P<0.05)$.

Within the moderately degraded site the biomass decreased slightly when cutting height was $3 \mathrm{~cm}$ and frequency increased, however, there was no significant difference of cutting frequency $(\mathrm{P}<0.1538)$ (Table 4; Fig. 2). On the other hand, cutting frequency had highly significant $(\mathrm{P}<.0001)$ effect when cutting height was $0 \mathrm{~cm}$. Effect of duration in years of treatments was not significant (Table 4). When cut at $0 \mathrm{~cm}$ the biomass was $30 \%$ less during the first year when cut four times compared with one cutting. After two and three years of cutting, the biomass was $37 \%$ and $50 \%$ less, respectively, when cut four times compared with one cutting (Fig. 2). The interaction between cutting frequency and cutting height are not significant $(\mathrm{P}>0.05)$ in all different year duration in moderately degraded sites (Table $3)$.

Within the heavily degraded site cutting height had significant effect on biomass when treatments had been repeated for two and three years (Table 3 ). In general, biomass was less in plots that were cut at $0 \mathrm{~cm}$ (Fig. 2). 
Cutting frequency was only significantly $(\mathrm{P}<0.0146)$ affecting biomass when cutting height was $3 \mathrm{~cm}$ and the duration of treatments was significant for $0 \mathrm{~cm}$ (Table 4).

Cutting experiment is not same as grazing by animals, but we can control the cutting

Table 4. Results of two-way ANOVA for above-ground biomass in plots harvested in 2009 within slightly degraded (SD), moderately degraded (MD) and heavily degraded (HD) sites. The abbreviations are; YDyear duration, CF-different cutting frequencies, bold figures indicate significant differences $(P<0.05)$

\begin{tabular}{|c|c|c|c|c|c|c|}
\hline \multirow{3}{*}{ Treatment } & \multirow{3}{*}{ Source } & \multirow{3}{*}{$D F$} & \multicolumn{4}{|c|}{ Cutting height } \\
\hline & & & \multicolumn{2}{|r|}{$3 \mathrm{~cm}$} & \multicolumn{2}{|c|}{$0 \mathrm{~cm}$} \\
\hline & & & $F$ & $\operatorname{Pr}>F$ & $\boldsymbol{F}$ & $\operatorname{Pr}>F$ \\
\hline \multirow{4}{*}{$\begin{array}{l}\text { Slightly } \\
\text { degraded }\end{array}$} & Replicate & 4 & 2.92 & 0.0314 & 1.17 & 0.3367 \\
\hline & YD & 2 & 1.84 & 0.171 & 12.76 & $<.0001$ \\
\hline & $\mathrm{CF}$ & 3 & 2.07 & 0.1176 & 20.34 & $<.0001$ \\
\hline & $\mathrm{YD} * \mathrm{CF}$ & 6 & 0.94 & 0.4739 & 1.25 & 0.2985 \\
\hline \multirow{4}{*}{$\begin{array}{l}\text { Moderately } \\
\text { degraded }\end{array}$} & Replicate & 4 & 1.7 & 0.166 & 1.46 & 0.2319 \\
\hline & YD & 2 & 0.15 & 0.8577 & 0.4 & 0.6707 \\
\hline & $\mathrm{CF}$ & 3 & 1.84 & 0.1538 & 13.28 & $<.0001$ \\
\hline & $\mathrm{YF} * \mathrm{CF}$ & 6 & 0.29 & 0.9369 & 1.18 & 0.3324 \\
\hline \multirow{4}{*}{$\begin{array}{l}\text { Heavily } \\
\text { degraded }\end{array}$} & Replicate & 4 & 3.69 & 0.0113 & 2.24 & 0.0802 \\
\hline & YD & 2 & 0.79 & 0.4581 & 6.38 & 0.0037 \\
\hline & $\mathrm{CF}$ & 3 & 3.92 & 0.0146 & 2.63 & 0.062 \\
\hline & $\mathrm{YD} * \mathrm{CF}$ & 6 & 1.24 & 0.3064 & 0.21 & 0.971 \\
\hline
\end{tabular}

It is well known that the intensity of grazing matters when it comes to health and sustainability of rangelands [13]. In a study in the northern Flint Region of Kansas three palatable forbs species from un-grazed, low, moderate and high-grazed areas was studied [9]. The results showed that when the grazing intensity increases, the total shoot biomass and percentage of reproductive stems of Ruellia humilis decreased. Also stem height reduced and total shoot biomass of Aster ericiodes significantly decreased due to increase in grazing intensity.

In a study in Inner Mongolia (China), grazing intensity negatively affected plant growth and dominant plant species changed from the original when moving from the reference area to heavy grazed area [13]. frequency, and frequency of duration. Intensive grazing has been having the worst effect on the above-ground biomass of 3 different degradation levels of Fescue-forbs rangeland in case of this study.

The above-ground biomass also decreased with increased degradation. Results from the Mongolian steppe zone also show that cover of grass and palatable species and above-ground biomass was lower in heavy grazed area as compared with the light-grazed area [19].

The percentage of annual above-ground biomass utilized by herbivores varies greatly, but estimates generally range between $20 \%$ and 50\% [4]. Although much higher levels of utilization can occur, in excess of $90 \%$, they are generally restricted to specific regions or year.

The results showed reduction of aboveground biomass due to different cutting frequencies and cutting heights (Fig. 2). More than two-times cutting frequency and lower $(0$ $\mathrm{cm}$ ) cutting height highly affected the above- 
ground biomass in slightly and moderately degraded Fescue-forbs rangeland. Within the heavily degraded site, the sod forming grass Carex duriuscula is dominant. This species is tolerant to grazing and usually grows in heavy grazed areas and is also a palatable species for livestock [20].

When cut four times, the cutting period started in May and ended in August, with one cutting per month, but started the following month as cutting frequency became lower (Table 2). It is well known that plants are more sensitive to grazing in spring and more resistent in summer. Studies carried out in Mongolia have shown that as cutting frequency increased the total biomass decreased during

\section{CONCLUSIONS}

The total above-ground biomass was influenced by cutting frequency and cutting height and duration of cutting. In general, biomass decreased with increased frequency and duration and lower cutting height. However, there is another important thing that strongly impacts the biomass production of a rangeland and that is the timing of grazing. It is obvious that grazing intensity is important when it comes to utilization and sustainability issues. This study shows that rangeland production or livestock forage are easily disturbed due to utilization but rangeland recovery is slow under Mongolia's dry conditions. Therefore, I would recommend that Mongolian herders and range managers adjust their grazing intensity the first year in meadow rangeland [3]. In the present study, we obtained similar results - with increased cutting frequency, the total biomass decreased in all three experimental sites when vegetation was cut at $0 \mathrm{~cm}$ (Fig. 2). Similar result was obtained in the Mongolian meadow rangeland. Cutting frequency was twice a year at $0 \mathrm{~cm}$, where the yield decreased by $25-44 \%$ in the second year but no biomass reduction was detected when cut at $3 \mathrm{~cm} \mathrm{[3].} \mathrm{The} \mathrm{year}$ duration was significantly different in terms of $0 \mathrm{~cm}$ cutting in slightly and heavily degraded sites, but no difference between years in moderately degraded sites in the Fescue-forbs rangeland (Table 4). in coherence with the rangeland health and weather conditions.

Acknowledgements: I would like to thank Prof. Dorligsuren Dulamsuren, Executive Director of Mongolian Society for Range Management, and Prof. Andreas Luescher scientific expert for "Green Gold Pasture Ecosystem Management Programme" of the Swiss Agency for Development and Cooperation in Mongolia for their grateful support and advice. I am very grateful to programme director Hafdís Hanna Ægisdóttir, Deputy Director of Berglind Orradóttir UNULRT programme in Iceland for the grateful support in preparing this paper.

\section{REFERENCES}

1. Archer, S., and F. E. Smeins. 1991. Ecosystem-level processes. Pp. 109-139 in R. K. Heitschmidt and J. W. Stuth, editors. Grazing management: an ecological perspective, Timber Press, Hong Kong.

2. Badarch, N. 1971. Mongolian climate. Mongolian Academy of Sciences Publishing House, Ulaanbaatar.

3. Bolormaa, B. 2008. Effects of cutting height and frequency on yield in a Mongolian rangeland. Report from LRT fellows 2008, Land Restoration Training Programme 2008.

4. Briske, D., and R. Heitschmidt. 1991. An ecological perspective. Pages 11-26 in R. K. Heitschmidt and J. W. Stuth, editors. Grazing management: an ecological perspective, 
Timber Press, Hong Kong.

5. Chognii, O. 1977. Change the community role of some plant species due to grazing in Stipaforb steppe. Proseeding Institute of Botany Mongolian Academy of Science 3:17-21.

6. Damiran, D. 2005. Palatability of Mongolian rangeland plants. Eastern Oregon Agricultural Research Center and Oregon State University Union, OR, USA.

7. Fernandez-Gimenez, M. E. 1999. Reconsidering the role of absentee herd owners: A view from Mongolia. Human Ecology 27:1-27.

8. Gunin, P. D. 1999. Vegetation dynamics of Mongolia. Kluwer Academic Publishers, Dordrecht, Netherlands.

9. Hickman, K. R., and D. C. Hartnett. 2002. Effects of grazing intensity on growth, reproduction, and abundance of three palatable forbs in Kansas tallgrass prairie. Plant Ecology 159:23-33.

10. Johnson, D. A., D. P. Sheehy, D. Miller, and D. Damiran. 2006. Mongolian rangelands in transition. Secheresse 17:133.

11. Lkhagvajav, N. 2000. The Scientifc Basis of Suitable Utilization and Possibility to Enhance Productivity of Pastureland in Khangai Mountain Zone. PhD Dissertation. Department of Agronomy, Mongolian State University of Agriculture, Ulaanbaatar.

12. Lkhagvajav, N., and L. Otgontuya. 2008. About Festuca lenensis. Plant Protection Ecology Journal 1:17-19.

13. Liang, Y., G. Han, H. Zhou, M. Zhao, H. A. Snyman, D. Shan, and K. M. Havstad. 2009. Grazing intensity on vegetation dynamics of a typical steppe in Northeast Inner Mongolia. Rangeland Ecology \& Management 62:328-336.

14. National Statistical Office, 1990. Livestock. National Statistical Office of Mongolia. http// www.nso.mn. (in Mongolian).

15. National Statistical Office, 2017. Monthly Bulletin of Statistics. National Statistical Office of Mongolia, http//www.nso.mn. (in Mongolian).

16. Sankey, T. T., J. B. Sankey, K. T. Weber, and C. Montagne. 2009. Geospatial assessment of grazing regime shifts and sociopolitical changes in a Mongolian Rangeland. Rangeland Ecology \& Management 62:522-530.

17. SAS. 2009. Administering SAS ${ }^{\circledR}$ Enterprise Guide ${ }^{\circledR}$ 4.2. SAS Institute Inc., Cary, NC, USA.

18. Tserendash, S. 1978. Biomass dynamic of Fescue-Stipa-forbs steppe. Institute of Botany Publication 4:35-43.

19. Yoshihara, Y., B. Chimeddorj, and B. Buuveibaatar. 2009. Heavy grazing constraints on foraging behavior of Mongolian livestock. Grassland Science 55:29-35.

20. Yunatov, A. A. 1954. Forage plants of pasture and meadow of the MPR. Mongolian Academ of Science, Ulaanbaatar. 